\title{
Inhibition of Monosodium Urate Crystal-Induced Inflammation by Withaferin A
}

\author{
Evan Prince Sabina ${ }^{1}$, Sonal Chandel ${ }^{1}$ and Mahaboob Khan Rasool ${ }^{2}$ \\ ${ }^{1}$ School of Biotechnology, Chemical and Biomedical engineering, VIT University Vellore - 632 014, Tamil Nadu, India. \\ ${ }^{2}$ Faculty of Health and Life Sciences, Management and Science University, 40100 Shah Alam, Malaysia.
}

Received October 15, 2008; Revised November 24, 2008; Accepted December 11, 2008, Published December 13, 2008.

\begin{abstract}
Purpose. Gouty arthritis is a characteristically intense acute inflammatory reaction resulting from the formation of sodium urate crystals in the joint cavity. In the present study, the effect of withaferin A, a steroidal lactone was investigated on monosodium urate crystalinduced inflammation in mice; an experimental model for gouty arthritis and compared it with that of the non-steroidal anti-inflammatory drug, indomethacin. Methods. Paw volume and levels/activities of lysosomal enzymes, lipid peroxidation, anti-oxidant status and inflammatory mediator TNF- $\alpha$ were determined in control and monosodium urate crystal-induced mice. The levels of $\beta$-glucuronidase and lactate dehydrogenase were also measured in monosodium urate crystalincubated polymorphonuclear leucocytes (PMNL). Results. Paw volume, the levels of lysosomal enzymes, lipid peroxidation, and inflammatory mediator tumour necrosis factor- $\alpha$ were found to be increased significantly and the activities of antioxidant status were in turn decreased in monosodium urate crystal-induced mice; however these changes were reverted back to near normal levels in withaferin A $(30 \mathrm{mg} / \mathrm{kg} / \mathrm{b} . w t$, i.p.) treated monosodium urate crystal-induced mice. In addition, $\quad \beta$-glucuronidase and lactate dehydrogenase level were reduced in withaferin $\mathrm{A}$ $(50 / 100 \mu \mathrm{g} / \mathrm{ml})$ treated monosodium urate crystalincubated polymorphonuclear leucocytes. Conclusion. The present findings clearly indicated that withaferin A exerted a strong antiinflammatory effect against gouty arthritis.
\end{abstract}

Corresponding Author: Dr. M. Rasool M.Sc., Ph.D. Faculty of Health and Life Sciences, Management and Science University, 40100 Shah Alam, Selangor, Malaysia, E-mail: mkr474@gmail.com or mkr474@rediffmail.com

\section{INTRODUCTION}

Gouty arthritis is a disease manifestated by an increase in serum urate concentration and deposits of monosodium rate monohydrate (MSU) in and around the joints of extremities with severe pain (1). Acute attacks of gout are often triggered by specific events such as trauma, surgery, intercurrent illness, excess alcohol intake or drugs that alter serum urate levels. Such events may stimulate de novo formation of MSU crystals or may trigger release of microcrystals from preformed deposits within the joint. In previous studies (2), monosodium urate crystals were demonstrated to stimulate synovial cells, monocytes-macrophages, and neutrophils to produce a variety of different cytokines including tumor necrosis factor (TNF-)- $\alpha$, interleukin (IL)-8, IL-1 $\beta$, IL-6, and monocyte chemotactic factor, which induce acute inflammation. The primary pathologic hallmark of gout is neutrophil influx into the joint fluid. Neutrophils accumulate in both the joint fluid and the synovial membrane, where a small fraction of these cells actively phagocytose MSU crystals resulting in membranolysis, generation of oxygen derived free radicals and the release of lysosomal enzymes, prostaglandin $E_{2}$, leukotrienes and interleukin-1 (3). Non-steroidal anti-inflammatory drugs such as indomethacin and naproxen are frequently used as first-line therapies for acute gout; however, these agents may have serious side effects such as gastrointestinal toxicity, renal toxicity, or gastrointestinal bleeding. Therefore we focussed our research to find out a drug with long acting antiinflammatory activity from natural resources.

Withanolides, the active constituents of Withania somnifera Dunal (Solanaceae) are group of pharmacologically active compounds present in roots and leaves. The chemistry of withanolides has been well studied and they are basically steroidal 
lactones. Withanolides are similar to ginsenosides (the active constituents of Panax ginseng) in structure and activity (4). Withaferin-A is best studied withanolide (5). Withaferin A (Figure 1), a steroidal lactone found in the leaves and roots of Withania somnifera L. Dunal (family-Solanaceae) has been reported to be inhibitor of immunologically-induced inflammation (6), angiogenesis, and protective in certain types of cancers with strong antioxidant properties (7). Many reports made it evident that Withania somnifera and its withanolides have suppressed the production of proinflammatory molecules and hold promise as novel anti-inflammatory agents (8-12). More over, in our earlier study, Withania somnifera root powder has been tested and reported to have anti-inflammatory effect on monosodium urate crystal-induced inflammation and adjuvant-induced arthritis in rats (13-14)). Therefore, in view of above, by considering its potential, the following study was undertaken to examine the antiinflammatory effect of Withaferin-A against monosodium urate crystal-induced inflammation in mice; an experimental model for gouty arthritis. To our knowledge, it is for the first time that antiinflammatory effect of withaferin A has been tested against monosodium urate crystal-induced inflammation. The standard non-steroidal antiinflammatory drug, indomethacin, was used as a reference drug for purposes of comparison.

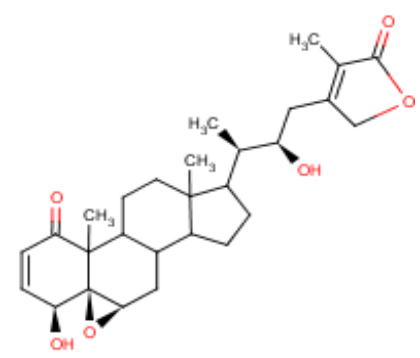

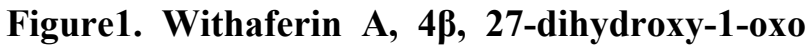
$5 \beta, 6 \beta$, epoxy with a 2-24 dienolide

\section{MATERIALS AND METHODS}

\section{Animals}

Swiss albino mice, 25-30g, of either sex were obtained from Tamil Nadu Veterinary College, Chennai, India. They were acclimatized for a week in a light and temperature -controlled room with a
$12 \mathrm{hr}$ dark-light cycle and fed with commercial pelleted feed from Hindustan Lever Ltd. (Mumbai, India) and water was freely available.

\section{Drug}

The commercially available withaferin A (a fine white crystalline powder, $>95 \%$ purity by HPLC, mol. wt. 470.61, Lot no: T7K047) was purchased from Natural Remedies Ltd., Bangalore, India and stored at $-20^{\circ} \mathrm{C}$. Indomethacin was purchased from Tamil Nadu Dadha Pharmaceuticals Ltd., Chennai, India. A homogenous suspension of withaferin A and indomethacin were made with $0.5 \%$ carboxy methyl cellulose in phosphate buffered saline. Fresh solution was prepared before each experiment. All other reagents used were standard laboratory reagents of analytical grade and were purchased locally.

\section{Dosage}

Based on our preliminary studies with different dosages $(10 \mathrm{mg}, 20 \mathrm{mg}, 30 \mathrm{mg}$ ) of this withaferin A, it was found that $30 \mathrm{mg} / \mathrm{kg}$ b.wt dosage produced significant anti-inflammatory effect by reducing paw swelling in monosodium urate crystal-induced animals. Hence $30 \mathrm{mg} / \mathrm{kg}$ b.wt dosage was considered for this study. The dosage of standard drug indomethacin $(3 \mathrm{mg} / \mathrm{kg}$ b.wt) used in this study was selected based on our previous reports (13-14).

\section{Synthesis of monosodium urate crystals}

About $4 \mathrm{~g}$ of uric acid was dissolved and heated in $800 \mathrm{ml} \mathrm{H}_{2} \mathrm{O}$ with $\mathrm{NaOH}(9 \mathrm{ml} / 0.5 \mathrm{~N})$, adjusted to pH 8.9 at $60^{\circ} \mathrm{C}$; cooled over night in a cold room; washed and dried. Needle-like crystals were recovered and were suspended in sterile saline $(20 \mathrm{mg} / \mathrm{ml})(13)$.

\section{Monosodium urate crystal-induced inflammation in mice}

The mice were divided into four groups-each comprising of six animals. Group I served as a control group. In Group II, inflammation was induced by intradermal injection of $0.2 \mathrm{ml}(4 \mathrm{mg})$ of monosodium urate crystal suspension into the right foot pad (13). Group III comprised of monosodium crystal-induced mice were treated with withaferin A 
(30 $\mathrm{mg} / \mathrm{kg}$ body weight, i. p.) and Group IV monosodium crystal-induced mice were treated with indomethacin ( $3 \mathrm{mg} / \mathrm{kg}$ body weight, i.p.). Withaferin $\mathrm{A}$ and indomethacin were suspended in $0.5 \%$ carboxy methyl cellulose in phosphate buffered saline and administered interaperitoneally, $1 \mathrm{~h}$ before the monosodium urate crystal injection and which was repeated for 3 more days on a daily basis.

\section{Assessment of Inflammation}

The inflammation was quantified by measuring the thickness of the paw with a vernier scale at different intervals for 3 days. At the end of the experimental period $(72 \mathrm{~h})$, the mice were killed by cervical decapitation. Blood from each animal was collected for serum separation. The liver and spleen were immediately dissected out and homogenized in icecold $0.01 \mathrm{M}$, Tris HCL buffer, $\mathrm{pH} 7.4$ to give a $10 \%$ homogenate. The tissue homogenate of spleen, liver and serum were used for assaying the lysosomal enzymes, lipid peroxidation, antioxidant status and inflammatory mediator tumour necrosis factor- $\alpha$.

\section{Effect of withaferin $A$ and indomethacin on lysosomal enzymes}

The activity of acid phosphatase was assayed by the method of King (15). $\beta$-glucuronidase was determined by the method of Kawai and Anno (16) and $\beta$-galactosidase by the method of Rosenblit (17). The method of Marhun (18) was followed for the determination of $\mathrm{N}$-acetyl glucosaminidase and the protein content was measured by the method of Lowry et al (19).

\section{Effect of withaferin A and indomethacin on lipid peroxidation and antioxidant status}

Lipid peroxidation in plasma was estimated by the method of Ledwozy et al (20). Spleen and liver lipid peroxidation were carried out by the procedure of Hogberg et al (21) using thiobarbituric acid as the colouring agent. Malonaldehyde (MDA) produced during peroxidation of lipids served as an index of lipid peroxidation. MDA reacts with TBA to generate a colour product, which absorbs at 532 $\mathrm{nm}$.

Superoxide dismutase (SOD) activity in spleen and liver was determined by the method of
Marklund and Marklund (22). The degree of inhibition of the auto-oxidation of pyrogallol at an alkaline $\mathrm{pH}$ by SOD was used as a measure of the enzyme activity. Catalase and Glutathione peroxidase activities in spleen and liver were estimated by the method of Sinha (23) and Rotruck et al (24). The activity of Catalase was expressed as $\mu \mathrm{g}$ of $\mathrm{H}_{2} \mathrm{O}_{2}$ consumed $/ \mathrm{mn} / \mathrm{mg}$ protein. Glutathione peroxidase was expressed as $\mu \mathrm{g}$ of glutathione utilized /minute $/ \mathrm{mg} /$ protein.

\section{Effect of withaferin $A$ and indomethacin on} TNF- $\alpha$ production

TNF- $\alpha$ levels in plasma, liver and spleen of control and monosodium urate crystal-induced mice were determined by enzyme-linked immunosorbent assay (ELISA, Cayman Chemicals Company, USA), according to the manufacturer's instruction.

\section{In vitro studies (monosodium urate crystal- PMNL cell interaction)}

Human PMNL cell suspension $\left(3 \times 10^{6} \mathrm{ml}^{-1}\right)$ was pre-incubated at $37^{\circ} \mathrm{C}$ for $20 \mathrm{~m}$ with withaferin A $(50 / 100 \mu \mathrm{g} / \mathrm{ml})$ or indomethacin $(10 \mu \mathrm{g} / \mathrm{ml})$ before addition of monosodium urate crystals $(1 \mathrm{mg} / \mathrm{ml})$. After incubation for a further $30 \mathrm{~m}$ at $37^{\circ} \mathrm{C}$, the cell suspension was removed and centrifuged at $1500 \times \mathrm{g}$ at $40{ }^{\circ} \mathrm{C}$ for $20 \mathrm{~m}$. The resulting cell free supernatant was assayed for the released activities of $\beta$-glucuronidase and lactate dehydrogenase. Appropriate control experiments were performed by measuring the release of enzymes tested in the untreated specimens and those incubated for $30 \mathrm{~m}$ at $37^{\circ} \mathrm{C}$ without drug. In all instances, the experiments were carried out in triplicate.

Lactate dehydrogenase (LDH), a cytoplasmic enzyme was assayed by the method of King (25). $\beta$-Glucuronidase, an enzyme present in azurophilic granules was measured by the method of Kawai and Anno (16). Enzyme released was expressed as a percentage of maximal enzyme release after disruption of the cells with Triton X100. Specific enzyme activity was expressed as units/mg of protein.

\section{STATISTICAL ANALYSIS}

Results were expressed as mean \pm S.D. and a statistical analysis was performed using ANOVA, to determine the significant differences between the 
groups, followed by Student's Newman-Keul's test. $\mathrm{P}<0.05$ implied significance.

\section{RESULTS}

Effect of withaferin A $(30 \mathrm{mg} / \mathrm{kg} / \mathrm{b} . \mathrm{wt})$ and indomethacin $(3 \mathrm{mg} / \mathrm{kg} / \mathrm{b}$.wt) on the activities of lysosomal enzymes in MSU crystal-induced mice

Table 1 represents the activity of withaferin A on lysosomal enzymes in the plasma, liver and spleen of control and experimental animals. Levels of acid phosphatase, $\quad \beta$-glucuronidase, $\quad \mathrm{N}$-acetyl glucosaminidase and $\beta$-galactosidase were found to be increased significantly in plasma, liver and spleen of monosodium urate crystal-induced mice when compared to that of control mice. These were found to be reverted back in withaferin A treated animals.

Effect of withaferin A $(30 \mathrm{mg} / \mathrm{kg} / \mathrm{b} . w t)$ and indomethacin $(3 \mathrm{mg} / \mathrm{kg} / \mathrm{b} . \mathrm{wt}) \quad$ on lipid peroxidation in MSU crystal-induced mice

Table 2 shows the effect of withaferin A on lipid peroxidation in plasma, liver and spleen of control and experimental mice. Lipid peroxide level in plasma, liver and spleen was increased significantly in monosodium urate crystal-induced mice when compared to control group. Administration of withaferin A to monosodium urate crystal-induced mice altered the above changes by regulating the lipid peroxide level to nearly that of normal levels.

\section{Effect of withaferin A $(30 \mathrm{mg} / \mathrm{kg} / \mathrm{b}$.wt $)$ and indomethacin $(3 \mathrm{mg} / \mathrm{kg} / \mathrm{b} . w \mathrm{t})$ on enzymic antioxidant status in MSU crystal-induced mice}

Table 3 shows the effect of withaferin $\mathrm{A}$ on the enzymic antioxidant levels in liver, and spleen of control and experimental mice. Significant reduction in the levels of enzymic antioxidants was observed in monosodium urate crystal-induced mice when compared to control mice. The administration of withaferin $\mathrm{A}$ increased the enzymic antioxidant levels in monosodium urate crystal-induced mice considerably, which indicates its antiperoxidative action.
Effect of withaferin A $(30 \mathrm{mg} / \mathrm{kg} / \mathrm{b}$.wt $)$ and indomethacin $(3 \mathrm{mg} / \mathrm{kg} / \mathrm{b} . w \mathrm{t})$ on monosodium urate crystal-induced paw oedema in mice

Fig. 2 portrays the effect of withaferin $\mathrm{A}$ on paw volume in the control and experimental animals. The paw volume of monosodium urate crystalinduced mice revealed an increase in ankle diameter, whereas withaferin A treatment reduces the paw diameter significantly in monosodium urate crystal- induced mice.

Effect of withaferin $A$ and indomethacin on enzyme leakage from the PMNL cells upon incubation with monosodium urate crystals

Fig. 3 shows the effect of withaferin $A$ and indomethacin on the $\beta$-glucuronidase (lysosomal) and lactate dehydrogenase (cytoplasmic) enzyme release from the PMNL cells incubated with monosodium urate crystals. The pretreatment of withaferin A $(50 / 100 \mu \mathrm{g} / \mathrm{ml})$ at the both dosages significantly suppresses the lysosomal and cytoplasmic enzyme release from the PMNL cells incubated with monosodium urate crystals compared to controls, i.e. untreated PMNL cells incubated with monosodium urate crystals. From the above results, it was observed that higher dose of withaferin A $(100 \mu \mathrm{g} / \mathrm{ml})$ produces significant inhibition of enzyme release from the PMNL cells incubated with monosodium urate crystals, when compared to low dosage withaferin A $(50 \mathrm{ug} / \mathrm{ml})$ and standard drug indomethacin.

Effect of withaferin $A(30 \mathrm{mg} / \mathrm{kg} / \mathrm{b} . w t)$ and indomethacin $(3 \mathrm{mg} / \mathrm{kg} / \mathrm{b} . w t)$ on TNF-alpha production in monosodium urate crystalinduced mice

Fig. 4 portrays the levels of pro-inflammatory cytokine tumour necrosis factor- $\alpha$ in the serum, liver and spleen of the control and experimental animals. Tumour necrosis factor- $\alpha$ level in the monosodium urate crystal mice was systemically overproduced in the serum, liver and spleen; while the elevated levels of tumour necrosis factor- $\alpha$ were found to be decreased in withaferin $A$ treated monosodium urate crystal-induced mice when compared to control mice. 


\section{DISCUSSION}

One of the most sensitive and dramatic indicator of gout is neutrophil influx into the joint fluid. Neutrophils accumulate in both the joint fluid and the synovial membrane, where a small fraction of these cells actively phagocytose monosodium urate crystals and release mediators, that are chemotactic and amplify the inflammatory reaction (26).

Table. 1 Effect of withaferin A $(30 \mathrm{mg} / \mathrm{kg} / \mathrm{b} . \mathrm{wt})$ and indomethacin $(3 \mathrm{mg} / \mathrm{kg} / \mathrm{b} \cdot \mathrm{wt})$ on the activities of lysosomal enzymes in MSU crystal-induced mice.

\begin{tabular}{|c|c|c|c|c|}
\hline Parameter & $\begin{array}{l}\text { Group -I } \\
\text { Control }\end{array}$ & $\begin{array}{l}\text { Group -II } \\
\text { MSU crystal- } \\
\text { induced mice }\end{array}$ & $\begin{array}{l}\text { Group -III } \\
\text { MSU crystal-induced } \\
\text { mice +withaferin A } \\
(30 \mathrm{mg} / \mathbf{k g ~ b . w t )}\end{array}$ & $\begin{array}{l}\text { Group -IV } \\
\text { MSU crystal-induced } \\
\text { mice + indomethcin } \\
(3 \mathrm{mg} / \mathrm{kg} \mathrm{b.wt})\end{array}$ \\
\hline \multicolumn{5}{|c|}{ 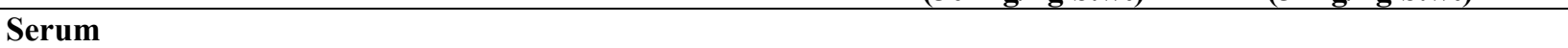 } \\
\hline Acid phosphatase & $0.11 \pm 0.01$ & $0.27 \pm 0.01 \mathrm{a}^{*}$ & $0.12 \pm 0.01 \mathrm{a}^{*} \mathrm{~b}^{*}$ & $0.14 \pm 0.01 \mathrm{a}^{*} \mathrm{~b}^{*}$ \\
\hline$\beta$-glucuronidase & $1.71 \pm 0.14$ & $3.78 \pm 0.27 \mathrm{a}^{*}$ & $1.83 \pm 0.20 \mathrm{a}^{*} \mathrm{~b}^{*}$ & $1.88 \pm 0.14 \mathrm{a}^{*} \mathrm{~b}^{*}$ \\
\hline $\mathrm{N}$-acetyl glucosaminidase & $0.85 \pm 0.06$ & $2.63 \pm 0.20 \mathrm{a}^{*}$ & $1.23 \pm 0.07 \mathrm{a}^{*} \mathrm{~b}^{*}$ & $1.41 \pm 0.18 \mathrm{a}^{*} \mathrm{~b}^{*}$ \\
\hline$\beta$-galactosidase & $1.88 \pm 0.15$ & $3.55 \pm 0.25 \mathrm{a}^{*}$ & $2.10 \pm 0.15 \mathrm{a}^{*} \mathrm{~b}^{*}$ & $2.26 \pm 0.16 \mathrm{a}^{*} \mathrm{~b}^{*}$ \\
\hline \multicolumn{5}{|l|}{ Liver } \\
\hline Acid phosphatase & $2.26 \pm 0.17$ & $3.70 \pm 0.41 \mathrm{a}^{*}$ & $2.46 \pm 0.05 \mathrm{a}^{*} \mathrm{~b}^{*}$ & $2.68 \pm 0.22 \mathrm{a}^{*} \mathrm{~b}^{*}$ \\
\hline$\beta$-glucuronidase & $27.7 \pm 2.13$ & $38.16 \pm 3.18 \mathrm{a}^{*}$ & $28.36 \pm 2.02 \mathrm{a}^{*} \mathrm{~b}^{*}$ & $29.03 \pm 2.07 \mathrm{a}^{*} \mathrm{~b} *$ \\
\hline $\mathrm{N}$-acetyl glucosaminidase & $28.78 \pm 3.59$ & $41.83 \pm 3.21 \mathrm{a}^{*}$ & $31.00 \pm 2.21 \mathrm{a}^{*} \mathrm{~b}^{*}$ & $31.83 \pm 2.65 \mathrm{a}^{*} \mathrm{~b}^{*}$ \\
\hline$\beta$-galactosidase & $8.33 \pm 0.59$ & $18.50 \pm 1.42 \mathrm{a}^{*}$ & $9.13 \pm 0.57 \mathrm{a}^{*} \mathrm{~b}^{*}$ & $9.43 \pm 0.67 a^{*} b^{*}$ \\
\hline \multicolumn{5}{|l|}{ Spleen } \\
\hline Acid phosphatase & $3.06 \pm 0.21$ & $4.85 \pm 0.37 \mathrm{a}^{*}$ & $3.23 \pm 0.26 \mathrm{a}^{*} \mathrm{~b}^{*}$ & $3.41 \pm 0.21 \mathrm{a}^{*} \mathrm{~b}^{*}$ \\
\hline$\beta$-glucuronidase & $23.65 \pm 1.99$ & $38.91 \pm 2.59 \mathrm{a}^{*}$ & $26.16 \pm 1.86 \mathrm{a}^{*} \mathrm{~b}^{*}$ & $26.83 \pm 1.57 a^{*} b^{*}$ \\
\hline $\mathrm{N}$-acetyl glucosaminidase & $21.21 \pm 2.35$ & $36.30 \pm 3.02 \mathrm{a}^{*}$ & $22.71 \pm 1.74 \mathrm{a}^{*} \mathrm{~b}^{*}$ & $23.88 \pm 1.99 \mathrm{a}^{*} \mathrm{~b}^{*}$ \\
\hline$\beta$-galactosidase & $3.56 \pm 0.25$ & $7.70 \pm 0.59 \mathrm{a}^{*}$ & $3.91 \pm 0.32 \mathrm{a}^{*} \mathrm{~b}^{*}$ & $4.06 \pm 0.31 \mathrm{a}^{*} \mathrm{~b}^{*}$ \\
\hline
\end{tabular}

Treatment of groups are as follows: Group I- Control mice; Group II -Monosodium urate crystal-induced mice; Group III- Monosodium urate crystal-induced mice treated with withaferin A $(30 \mathrm{gm} / \mathrm{kg} / \mathrm{b}$.wt); Group IV- Monosodium urate crystal-induced mice treated with indomethacin $(3 \mathrm{mg} / \mathrm{kg} / \mathrm{b}$.wt). Values are expressed as mean \pm S.D. of six animals. Comparisons were made as follows: (a) - Group-1 vs. Groups- II, III, and IV (b) - Group-II vs. Group- III, and IV. Enzyme activities are expressed as: Acid phosphatase $-\mu$ moles $\times 10^{-2}$ of phenol; $\beta$-glucuronidase, $\mathrm{N}$-acetyl glucosaminidase and $\beta$-Galactosidase- $\mu$ moles $\times 10^{-2}$ of $\mathrm{p}$ - nitro phenol liberated $/ \mathrm{h} / \mathrm{mg}$ protein. The symbols represent statistical significance at: $* \mathrm{p}<0.05$. Statistical analysis was calculated by one way ANOVA followed by Student's Newman-Keul's test .

Table 2. Effect of withaferin A (30 mg $/ \mathrm{kg} / \mathrm{b} . w \mathrm{t})$ and indomethacin $(3 \mathrm{mg} / \mathrm{kg} / \mathrm{b} . \mathrm{wt})$ on lipid peroxidation in MSU crystalinduced mice.

\begin{tabular}{|c|c|c|c|c|}
\hline Parameter & $\begin{array}{l}\text { Group-I } \\
\text { Control }\end{array}$ & $\begin{array}{l}\text { Group II MSU } \\
\text { crystal-induced } \\
\text { mice) }\end{array}$ & $\begin{array}{l}\text { Group III MSU crystal } \\
\text { induced mice+ withaferin-A } \\
(30 \mathrm{mg} / \mathrm{kg} / \mathrm{b} . \mathrm{wt})\end{array}$ & $\begin{array}{l}\text { Group IV (MSU crystal- } \\
\text { induced mice+indomethacin } \\
(3 \mathrm{mg} / \mathrm{kg} / \mathrm{b} . w \mathrm{wt})\end{array}$ \\
\hline Plasma & $2.86 \pm 0.22$ & $4.76 \pm 0.34 \mathrm{a}^{*}$ & $3.13 \pm 0.19 \mathrm{a}^{*} \mathrm{~b}^{*}$ & $3.21 \pm 0.20 \mathrm{a}^{*} \mathrm{~b}^{*}$ \\
\hline Liver & $1.26 \pm 0.09$ & $2.36 \pm 0.14 \mathrm{a}^{*}$ & $1.50 \pm 0.09 \mathrm{~b}^{*}$ & $1.61 \pm 0.11 b^{*}$ \\
\hline Spleen & $2.10 \pm 0.16$ & $3.81 \pm 0.23 \mathrm{a}^{*}$ & $2.21 \pm 0.18 \mathrm{a}^{*} \mathrm{~b} *$ & $2.31 \pm 0.14 \mathrm{a}^{*} \mathrm{~b}^{*}$ \\
\hline
\end{tabular}

Treatment of groups are as follows: Group I- Control mice; Group II -Monosodium urate crystal-induced mice; Group III- Monosodium urate crystal-induced mice treated with withaferin A $(30 \mathrm{mg} / \mathrm{kg} / \mathrm{b}$.wt); Group IV- Monosodium urate crystal-induced mice treated with indomethacin $(3 \mathrm{mg} / \mathrm{kg} / \mathrm{b}$.wt). Values are expressed as mean \pm S.D. of six animals. Comparisons were made as follows: a- Group-1 vs. Groups- II, III, and IV b- Group-II vs. Group- III, and IV Values are expressed as: nanomoles of malonaldehyde formed /mg protein; plasma-mg/dl The symbols represent statistical significance at: $* \mathrm{p}<0.05$. Statistical analysis was calculated by one way ANOVA followed by Student's Newman-Keul's test. 
Table 3. Effect of withaferin A (30mg/kg/b.wt) and indomethacin $(3 \mathrm{mg} / \mathrm{kg} / \mathrm{b} . \mathrm{wt})$ on enzymic antioxidant status in MSU crystal-induced mice.

\begin{tabular}{lllll}
\hline Parameter & $\begin{array}{l}\text { Group-I } \\
\text { Control }\end{array}$ & $\begin{array}{l}\text { Group II MSU } \\
\text { crystal- } \\
\text { induced mice }\end{array}$ & $\begin{array}{l}\text { Group III MSU crystal- } \\
\text { induced mice +withaferin } \\
\text { A (30 } \mathbf{~ m g} / \mathbf{k g} / \mathbf{b} . \mathbf{w t})\end{array}$ & $\begin{array}{l}\text { Group IV MSU crystal- } \\
\text { induced mice +indomethacin } \\
\mathbf{( 3 m g / k g / b . w t )}\end{array}$ \\
\hline Liver & & & & \\
Superoxide dismutase (SOD) & $3.2 \pm 0.21$ & $1.91 \pm 0.11 \mathrm{a}^{*}$ & $2.91 \pm 0.24 \mathrm{a}^{*} \mathrm{~b}^{*}$ & $2.86 \pm 0.23 \mathrm{a}^{*} \mathrm{~b}^{*}$ \\
Glutathione peroxidase (Gpx) & $8.45 \pm 0.65$ & $5.15 \pm 0.36 \mathrm{a}^{*}$ & $8.06 \pm 0.54 \mathrm{a}^{*} \mathrm{~b}^{*}$ & $7.98 \pm 0.57 \mathrm{a}^{*} \mathrm{~b}^{*}$ \\
Catalase & $10.76 \pm 0.83$ & $5.61 \pm 0.43 \mathrm{a}^{*}$ & $9.96 \pm 0.83 \mathrm{a}^{*} \mathrm{~b}^{*}$ & $9.83 \pm 0.75 \mathrm{a}^{*} \mathrm{~b}^{*}$ \\
Spleen & & & & \\
Superoxide dismutase (SOD) & $2.48 \pm 0.17$ & $1.21 \pm 0.07 \mathrm{a}^{*}$ & $2.11 \pm 0.15 \mathrm{~b}^{*}$ & $2.06 \pm 0.17 \mathrm{a}^{*} \mathrm{~b}^{*}$ \\
Glutathione peroxidase (Gpx) & $5.13 \pm 0.36$ & $3.68 \pm 0.26 \mathrm{a}^{*}$ & $4.83 \pm 0.30 \mathrm{~b}^{*}$ & $4.73 \pm 0.36 \mathrm{~b}^{*}$ \\
Catalase & $10.26 \pm 0.73$ & $6.26 \pm 0.48 \mathrm{a}^{*}$ & $9.46 \pm 0.72 \mathrm{a}^{*} \mathrm{~b}^{*}$ & $9.35 \pm 0.77 \mathrm{a}^{*} \mathrm{~b}^{*}$ \\
\hline
\end{tabular}

Treatment of groups are as follows: Group I- Control mice; Group II -Monosodium urate crystal-induced mice; Group III- Monosodium urate crystal-induced mice treated with withaferin A $(30 \mathrm{mg} / \mathrm{kg} / \mathrm{b}$.wt); Group IV- Monosodium urate crystal-induced mice treated with indomethacin $(3 \mathrm{mg} / \mathrm{kg} / \mathrm{b}$.wt). Values are expressed as mean \pm S.D. of six animals. Comparisons were made as follows: a- Group-1 vs. Groups- II, III, and IV b- Group-II vs. Group- III, and IV Enzyme units are expressed as; SOD-units $/ \mathrm{mg}$ protein (unit-amount of enzyme required to inhibit the auto-oxidation reaction by 50 $\%$; Gpx- $\mu$ g of GSH utilised / $\mathrm{min} / \mathrm{mg}$ protein; Catalase- $\mu \mathrm{mol}$ of $\mathrm{H}_{2} \mathrm{O}_{2}$ consumed $/ \mathrm{min} / \mathrm{mg}$ protein. The symbols represent statistical significance at: * $\mathrm{p}<0$.05. Statistical analysis was calculated by one way ANOVA followed by Student's Newman-Keul's test.

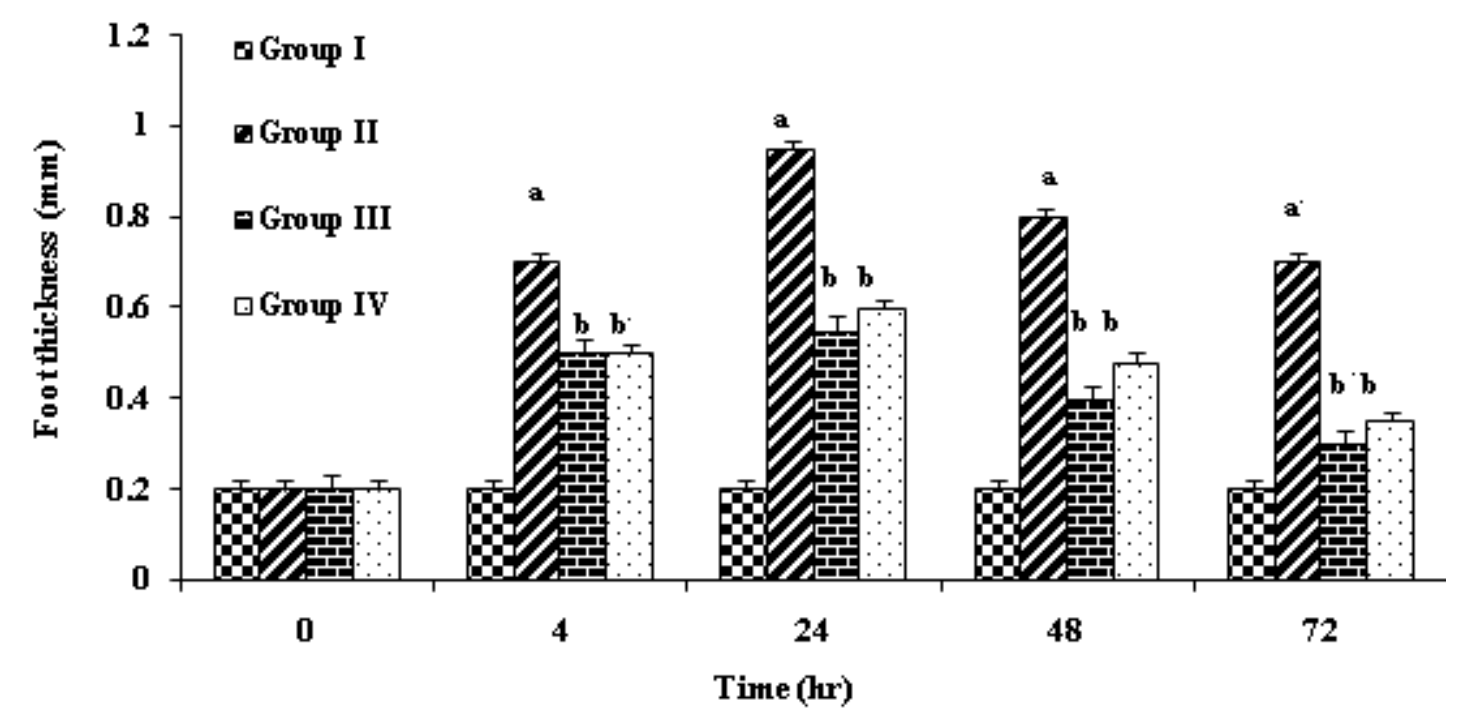

Figure 2. Effect of withaferin $A$ and indomethacin on monosodium urate-induced paw oedema in mice.

Treatment of groups are as follows: Group I- Control mice; Group II -Monosodium urate crystal-induced mice; Group III- Monosodium urate crystal-induced mice treated with withaferin A $(30 \mathrm{mg} / \mathrm{kg} / \mathrm{b}$.wt);Group IVMonosodium urate crystal-induced mice treated with indomethacin $(3 \mathrm{mg} / \mathrm{kg} / \mathrm{b} . \mathrm{wt})$. Values are expressed as mean \pm S.D. of six animals. Comparisons were made as follows: a- Group-1 vs. Groups- II, III, and IV; bGroup-II vs. Group- III, and IV; Different characters indicates statistical significance at * $p<0.05$. 


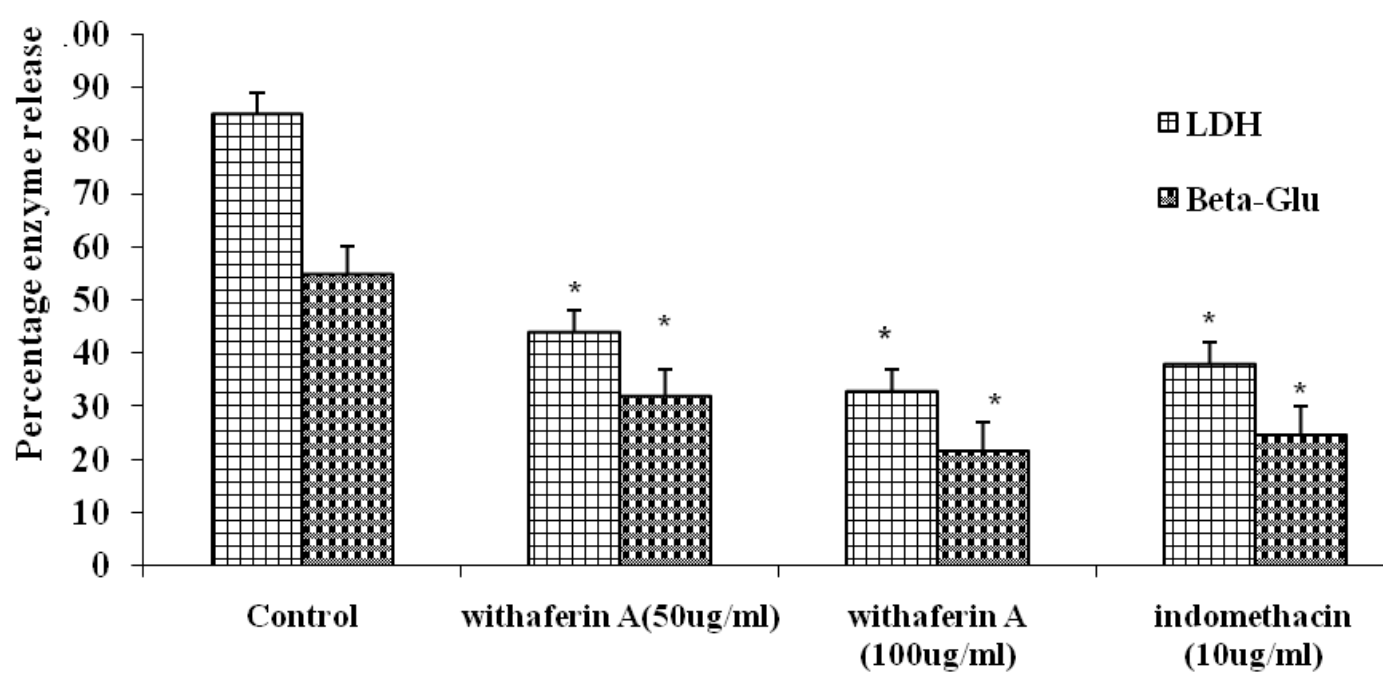

Treatment

Figure 3. Effect of withaferin A and indomethacin on enzyme leakage from the PMNL cells upon incubation with monosodium urate crystals. Values are expressed as mean \pm S.D. of six animals. Comparisons were made with control groups. Astrite incicates statistical significances between groups at $\mathrm{p}<$ 0.05 .

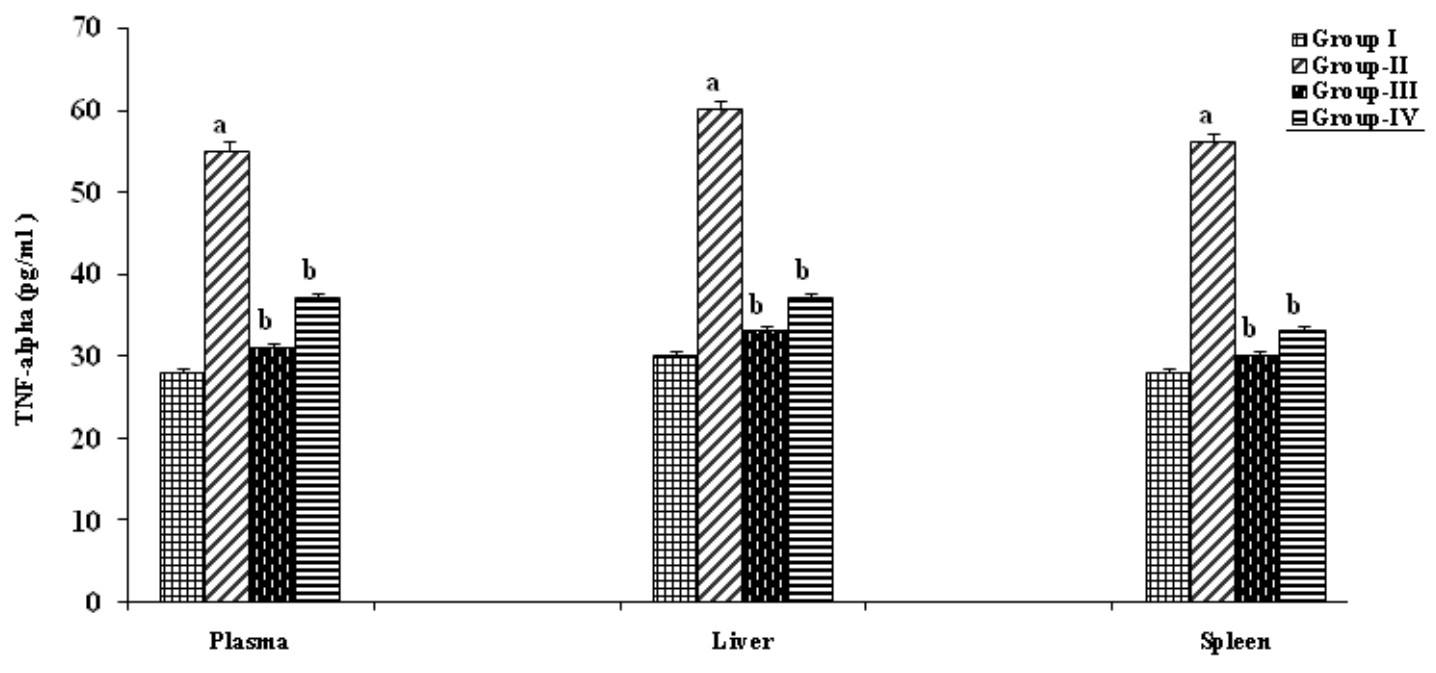

Figure. 4 Effect of withaferin A and indomethacin on TNF-alpha production in MSU crystal-induced mice.

Treatment of groups are as follows: Group I- Control mice; Group II -Monosodium urate crystal-induced mice; Group III- Monosodium urate crystal-induced mice treated with withaferin A $(30 \mathrm{mg} / \mathrm{kg} / \mathrm{b}$.wt); Group IV-Monosodium urate crystal-induced mice treated with indomethacin $(3 \mathrm{mg} / \mathrm{kg} / \mathrm{b}$.wt). Values are expressed as mean \pm S.D. of six animals. Comparisons were made as follows: (a) - Group-1 vs. Groups- II, III, and IV (b) - Group-II vs. Group- III, and IV. Different characters indicates statistical significance at * p $<0.05$. 
In the present study, injection of monosodium urate crystals in mice results in transient neutrophilic inflammation that resembles acute gouty arthritis in humans (27). Paw volume and lysosomal enzymes were found to be increased in monosodium crystalinduced mice. Lysosomes and lysosomal enzymes are the main factors playing a vital role in tissue injury and repair, inflammation, phagocytosis and they participate in pathologic processes such as inflammation, degeneration, cancer and rheumatoid arthritis (28). It was further postulated that the lysosomal enzymes are released in inflammatory diseases to stimulate the synthesis of prostaglandins (29). Since, extracellular release of lysosomal enzymes may be crucial to the pathogenesis of tissue injury and inflammation (30), it is likely that a reduction in the release of such enzymes would prove beneficial. The reduction in the paw edema and lysosomal enzyme activities after withaferin A treatment suggest that this drug can inhibit the release of lysosomal enzymes by its stabilizing action. Anti-inflammatory effect of withaferin A observed in our study may be due to its membrane stabilizing effects.

In recent years, there is increasing interest in free radicals; they have been shown to modify biological molecules, which may result in various pathological conditions. Thus additional natural products need to be evaluated for their antioxidant potential. Considerable evidence suggests that oxidative stress and reactive oxygen species (ROS) play significant roles in several aspects of acute and chronic inflammation (31). The increased lipid peroxide level noticed in monosodium urate crystalinduced mice in our study (Group II) may be due to its release from neutrophils and monocytes during inflammation. The result of the present study indicate that the antioxidant defense system is compromised in monosodium urate crystal-induced mice as evidenced by increased lipid peroxidation concentration and decreased activity of antioxidant enzyme, which in turn falls in line with our earlier report (13). Our results show that the activities of Superoxide dismutase, Glutathione peroxidase and Catalase are found to be decreased in monosodium urate crystal-induced animals which may be due to consequence of their increased consumption during oxidative stress and cellular lysis. However, augmented lipid peroxidation observed in monosodium urate-induced animals has been compromised and counterbalanced by withaferin A via by scavenging free radicals as well as enhancing the antioxidant systems. Inspite of its antioxidant property, recent studies reported that withaferin A plays a vital role in antiinflammation by inhibiting the expression of proinflammatory cytokines, NF$\kappa \mathrm{B}$ activation cascade and consequently arresting proinflammatory gene expression (10). This argument was supported in our study by the depleted tumour necrosis factor- $\alpha$ level in withaferin treated monosodium urate crystalinduced mice when compared to monosodium urate crystal-induced mice.

Monosodium urate crystals can interact with cells by phagocytosis or direct interaction with cell surface receptors. Intense infiltration of neutrophils into both synovial membrane and fluid is the hall mark of gout and these cells provide main cellular mechanism of inflammatory amplification. The consequences of neutrophil interaction with monosodium crystals include the synthesis and release of a large variety of mediators like lysosomal enzymes, reactive oxygen species, prostaglandin E2 and chemokines that promote vasodilation, erythema, and the pain associated with acute gout attack (3). In the present study, human polymorphonuclear leucocyte (PMNL) cells, significantly released $\beta$-glucuronidase and lactate dehydrogenase upon exposure to monosodium urate crystals. Monosodium urate crystals can cause enzyme release from PMNL cells mainly by a direct effect on the plasma membrane. Wallingford and McCarty (32) hypothesized that hydrogen donor sites on the crystal attach to acceptor sites on the outer surface of the lipid bilayer of cell membranes. Interaction between crystals and cell membrane can also alter cellular metabolism, and cause secretion of inflammatory mediators. Thus, urate crystals induce release of lysosomal enzymes from leucocytes in the absence of phagocytosis. Withaferin A treatment suppressed the enzyme release from the PMNL cells incubated with monosodium urate crystals, suggesting that it plays a beneficial role in inhibiting the membrane damage induced by these crystals.

$\mathrm{PGD}_{2}$, a pleiotropic prostanglandin and transforming growth factor (TGF)- $\beta$ have been strongly associated with anti-inflammatory effects and resolution of inflammation (33). Although in our present study, we did not assay $\mathrm{PGD}_{2}$ and TGF- 
$\beta$ levels, from the above results, it is possible that withaferin A treatment might arrest the proinflammatory gene expression which has been already reported (10), as well as, it might raise the levels of $\mathrm{PGD}_{2}$ and TGF- $\beta$ in monosodium urate crystal-induced mice. In conclusion, in the present study, withaferin A diminished monosodium urate crystal-induced inflammation in mice by reducing lysosomal enzymes, lipid peroxidation and proinflammatory cytokine TNF- $\alpha$ and paw volume. These evidences prompted us to investigate the effect of withaferin A against acute gouty arthritis at molecular level to establish its exact mechanism of the action which is underway.

\section{REFERENCES}

[1]. Schweyer S, Hemmerlein B, Radzun HJ, Fayyazi A. Continuous recruitment, co-expression of tumour nerosis factor-alpha and matrix metallo proteinases, and apoptosis of macrophages in gout tophi. Virchows Arch, 2000; 437: 534-539.

[2]. Di Giovine FS, Malawista SE, Nuki G, Duff GW. Interleukin 1 (IL 1) as a mediator of crystal arthritis. Stimulation of $\mathrm{T}$ cell and synovial fibroblast mitogenesis by urate crystal-induced IL 1, J Immunol, 1987; 138: 3213-3218.

[3]. Terkeltaub R. Pathogenesis and treatment of crystal-induced inflammation. In: Koopman WJ, Moreland LW (eds), Arthritis and Allied conditions, Philadelphia, Lippincott, Williams and Wilkins, pp, 2357-2372, 2004.

[4]. Grandhi A, Mujumdar AM, Patwardhan B. A comparative pharmacological investigations of Ashwagandha and Ginseng. J. Ethanopharmacol, 1994;44: 131-135.

[5]. Ali M, Shuaib M. Withanolides from the stem bark of Withania somnifera. Phytochemistry, 1997; 44(6): 1163-1168.

[6]. Fugner A. Inhibition of immunologically induced inflammation by the plant steroid withaferin A. Arzneimittelforschung 1973; 23(7): 932-935.

[7]. Mohan R, Hammers HJ, Bargagna-Mohan P, Zhan XH. Herbstritt CJ, Ruiz A. Withaferin A is a potent inhibitor of angiogenesis. Angiogenesis, 2004; 7:115-22.

[8]. Singh D, Aggarwal A, Maurya R, Naik S. Withania somnifera inhibits NF-kappa B and AP1 transcription factors in human peripheral blood and synovial fluid mononuclear cells. Phytother Res, 2007; 21(10): 905-913.

[9]. Ichikawa H, Takada Y, Shishodia S, Jayaprakasam B, Nair MG, Aggarwal BB. Withanolides potentiate apoptosis, inhibit invasion, and abolish osteoclastogenesis through suppression of nuclear factor-kappaB (NFkappaB) activation and NF-kappaB-regulated gene expression. Mol Cancer Ther, 2006; 5(6):1434-45.

[10]. Kaileh M, Berghe WV, Heyerick A, Horion J, Piette J, Liber C, Keukeleir DD, Essawi T, and Haegeman G. Withaferin A Strongly Elicits Ikk beta Hyperphosphorylation Concomitant with Potent Inhibition of Its Kinase Activity. J. Biol. Chem, 2007;7: 4253-4264.

[11]. Begum VH, Sadique J. Long term effect of herbal drug Withania somnifera on adjuvant-induced arthritis in rats. Indian J Exp Biol, 1988; 26 (11): 877-882.

[12]. Anbalagan K, Sadique J. Influence of Indian medicine (Ashwagandha) on acute phase reactants in inflammation Indian J Exp Biol, 1981; 19(3): 245-9.

[13]. Rasool M, Varalakshmi P. Suppressive effect of Withania somnifera root powder on MSU crystalinduced Inflammation- an in vivo and in vitro study. Chem-Biol Interact, 2006; 164(3): 174-80.

[14]. Rasool M, Varalakshmi P. Protective effect of Withania somnifera root powder in relation to lipid peroxidation, antioxidant status, glycoproteins and bone collagen on adjuvantinduced arthritis in rats. Fundam Clin Pharmacol, 2007; 21(2):157-64.

[15]. King J. The hydrolases-acid and alkaline phosphatases, In: Van D (ed), Practical clinical enzymology, Nostrand Company Limited, London, pp, 191-208, 1965b.

[16]. Kawai Y, Anno K. Mucopolysaccharidedegrading enzymes from the liver of the Squad, Ommastrephesslonaipacificus.I.Hyaluronidase. Bi ochim.Biophys.Acta, 1971; 242: 428-436.

[17]. Rosenblit PD, Metzyer RP, Wick AN. Effect of Streptozotocin diabetes on acid phosphatase and selected glycosidase activities of serum and various rat organs. Proc. Soc. Exp. Biol Med, 1974; 145: 244-247.

[18]. Marhun D. Rapid colorimetric assay of $\beta$ galactosidase and $\mathrm{N}$-acetyl- $\beta$ - galactosaminidase in human urine. Clin.Chim.Acta, 1976;73: 453461.

[19]. Lowry OH, Rosebrough NJ, Farr AI, Randall RJ. Protein measurement with the folin phenol reagent. J.Biol.Chem, 1951; 193: 265-275.

[20]. Ledwozyw A, Michalak J, .Stepien A, Kadziolka A. The relationship between plasma triglycerides, cholesterol, total lipids and lipid peroxidation products during human atherosclerosis. Clin.Chim.Acta, 1986;155: 275-284.

[21]. Hogberg J, Larson RE, Kristoferson A, Orrenius S. NADPH-dependent reductase solubilised from 
microsomes of peroxidation and its activity. Biochem.Biophys.Res.Commun, 1974; 56: 836842.

[22]. Marklund SL, Marklund G. Involvement of superoxide anion radical in the autoxidation of pyrogallol and a convenient assay for superoxide dismutase. Eur. J. Biochem, 1974; 47: 469-474.

[23]. Sinha AK. Colorimetric assay of Catalase. Anal.Biochem, 1972; 47: 389-394.

[24]. Rotruk JT, Pope AL, Ganther HE, Swanson AB, Hafeman DG, Hekstra WG. Selenium, biochemical role as a component of glutathione peroxidase purification and assay. Science, 1973;179: 588-590.

[25]. King J. The dehydrogenase or oxidoreductaselactate dehydrogenase. In: Van D (ed), Practical Clinical Enzymology, Nostrand, London, pp, 8393, 1965.

[26]. Landis RC, Haskard DO. Pathogenesis of crystalinduced inflammation. Curr Rheumatol Rep, 2001; 3:36-41.

[27]. Tate GA, Mandell BF, Schumacher HR Jr, Zurier RB. Suppression of acute inflammation by 15 methyl prostaglandin E1. Lab Invest, 1988; 59:192-199.
[28]. Gallin JI. The neutrophil. In: Samber M, Talmage DW, Frank MM, Austen KF, Claman HN, ed. Immunological diseases, Little Brown Co., Boston, MA, pp, 737-788, 1988.

[29]. Gupta OP, Sharma N, Chand DA. Sensitive and selective model for evaluating anti-inflammatory activity-papaya latex-induced rat paw inflammation. J Pharmacol Toxicol Methods, 1992; 28 (1): 15-19.

[30]. Rasool M, Sabina EP, Lavanya B. Antiinflammatory effect of Spirulina fusiformis on adjuvant-induced arthritis in mice, Biol. Pharm Bull, 2006; 29(1):2483-7.

[31]. Ramprasad VR, Shanthi P, Sachdanandam P. Evaluation of antioxidant effect of Semecarpus anacardium Linn.nut extract on thecomponents of immune system in adjuvant arthritis. Vasc. Pharmacol, 2005; 42: 179-186.

[32]. Wallingford WR, McCarty DT. Differential membronolytic effects of sodium urate and calcium pyro phosphate dihydrate crystals, J. Exp. Med, 1971; 133: 100.

[33]. Lawrence T, Willoughby DA, Gilroy DW. Antiinflammatory lipid mediators and insights into the resolution of inflammation. Nat Rev Immunol, 2002; 2:787-795. 